\title{
Local Food Potentials and Agroecology in Yogyakarta Special Province, Indonesia
}

\author{
Dodi Widiyanto \\ Graduate School of Environmental Studies, Nagoya University, Furo-cho, Chikusa-ku, Nagoya, \\ 464-8601, Japan. \\ The Faculty of Geography, Universitas Gadjah Mada, Jl. Kaliurang Km. 5 Bulaksumur, Sleman, \\ Yogyakarta 55281, Indonesia. \\ Corresponding author (e-mail: dodi.widiyanto@ugm.ac.id)
}

Received: 27 February 2019 / Accepted: 30 July 2019 / Published: 01 August 2019

\begin{abstract}
This paper attempts to unveil the hidden potential of the local food through local food mapping, drawing local food potential based on the "triple burden" theory from Professor Moerdijati Gardjito. An index, called "index of food relocalisation" is adopted and then modified into different name called local food index due to data availability, which is expected to provide a geographical location of the local food potential by proposing a research questions: where do the local food potentials distribute in Yogyakarta Special Province, and why the local food potentials located in that particular area(s)? The findings show that Gunungkidul and Kulonprogo are two potential regencies with their local food crops availabilities This finding is accompanied by an explanation from the analysis from the agroecological subzone and spatial income distribution of paddy and second crops, production activities.
\end{abstract}

Keywords: hidden potential, "triple burden", local food index, cross-tabulation matrix, agroecology

\begin{abstract}
Abstrak. Paper ini berupaya untuk menyingkap tabir "potensi tersembunyi" dari pangan lokal dengan cara memetakan potensi pangan lokal berdasarkan teori "triple burden" sebagaimana yang diajukan oleh Profesor Moerdijati Gardjito. Penelitian ini juga mengadopsi sebuah indeks: index of food relocalisation dan kemudian dimodifikasi dengan nama indeks pangan lokal dikarenakan alasan ketersediaan data. Pertanyaan penelitian utama dari kajian ini adalah dimanakah distribusi potensi pangan lokal di Daerah Istimewa Yogyakarta (DIY)? Selanjutnya, pertanyaan kunci tersebut dilengkapi dengan pertanyaan berikutnya: mengapa potensi potensi pangan lokal tersebut terkonsentrasi di tempat tersebut? Temuan dari penelitian ini menunjukkan bahwa Kabupaten Gunungkidul dan Kulonprogo adalah dua kabupaten dengan potensi pangan lokal tertinggi di DIY. Penelitian ini juga dilengkapi dengan kajian agroekologi dan distribusi keruangan pendapatan menurut usaha padi dan palawija.
\end{abstract}

Kata kunci: potensi tersembunyi, "triple burden", indeks pangan lokal, matriks tabel silang, agroekologi

\section{Introduction}

According to the data from Badan Ketahanan Pangan Kementerian Pertanian (Food Security Agency of the Ministry of Agriculture), Kompas reports that Indonesia stands for the second richest country for the food potentials due to the availability of 77 types of carbohydratefood crops, 75 kinds of fat, 26 types of nuts, 389 fruits, 228 types of vegetables and 110 kinds of spices (Kompas, 2018). However, even though Indonesia has various food resources, rice is the most favoured food choice compared to others 
(Sumedi \& Heriawan, 2016). The Indonesian long-term habits of rice consumption will not easily change because of Indonesian cultural and psychological perspective (Sumedi \& Heriawan, 2016). It is common that most the Indonesian felt not to meal if they do not eat rice (GardjitoM, Djuwardi, \& Harmayani, 2013).

According to Rahardjo and Ritohardoyo (2002), most Indonesian depend on rice not only for their staple food but also their livelihood. Moreover, Rahardjo and Ritohardoyo explain that the rice dependency causes several problems on the food systems, such as on the production, consumption, distribution, monitoring, estimation and data validity (Rahardjo \& Ritohardoyo, 2002). Harian Jogja (a regional newspaper) reports that rice production is abundant in Yogyakarta Special Province (Daerah Istimewa Yogyakarta, hereafter DIY) (Mustika, Sunartono, \& Saraswati, 2017). However, Food Security Agency \& Extension DIY (BKPP DIY) calculates that there is a decline in rice production and increase in rice consumption during the last five years (Mustika et al., 2017). Following the trend of DIY's rice production and consumption, and using information provided by BKPP DIY, Mustika et al. estimate that by 2027 the DIY's rice production will not adequate to fulfil the inhabitants rice consumption (Mustika et al., 2017). The gap between rice production and consumption in DIY will perhaps bring about a food crisis in 2037 based on BKPPDIY prediction (Kedaulatan Rakyat, 2017). In order to avoid food insecurity, malnutrition or food crisis, BKPP DIY offers a food diversification strategy (Kedaulatan Rakyat, 2017; Mustika et al., 2017; Tribun Jogja, 2017). Therefore, providing food backup is necessary to anticipate a lack of food supply. In the past, indeed, the Javanese planted cassava as food backup (Nawiyanto, 2003). Jhamtani described some cases of food insecurity and malnutrition due to various factors, such as climate change, lack of food access and lack of staple food alternatives (Jhamtani, 2008). As these alternatives, local food that is primarily defined as non-rice staple food is increasingly important.
Gardjito (2017), an Indonesian expert of local food and gastronomy, proposed a term: "triple burden". For my interview, she points out: 1) most people pay less attention or neglect the local food potentials, 2) there is no or lack of institutional data of local food, and 3) less information leads to difficulties for the central and/or regional government to design policies regarding local food. She explains that local food has a "hidden" potential (Gardjito, 2017). Why is local food neglected? How to answer this question can be identified from the policy and technical constraints (Rijanta2, Widiyanto, Toekidjo, \& Sulistyani, 2013) and the Indonesian (local) food culture (Simatupang, 2016; Sumarno, 2016). The second issue is the availability of local food data. Erwidodo (2016) states a difficulty in collecting local food data particularly from a locality dimension. In particular, Suryana (2016) mentions the lack of quantitative data for local food. The lack of accuracy of data consequently causes difficulty in providing a piece of valid information.

Following the "triple burden" idea, local food is seen as having a "hidden potential" through the lenses of food availability in Indonesia. As for why studying local food from the geographical perspective is important, following Jean-Luc Maurer, a professor of development studies, Rotgé (2000) reviews the rice agricultural modernisation programme in DIY and gives an analysis that the geographical location and the agroecological types supports economic security of the local inhabitants. Following Rotgé's arguements (Rotgé, 2000), first of all, this study identifies the location of the local food potentials in order to explore where they "hide". For details, the main research question of this study is where the local food potentials are distributed in DIY. The main research question is then expanded into whether local food potentials concentrate in the particular places or disperse in the wider area of DIY, and how these patterns of local food potentials are related to the local geographies.

This paper attempt to contribute to the geography of local food systems studies, focus on two perspectives of production and spatial 
(Reid, Gatrell, \& Ross, 2012/2016a, 2012/2016b). Four dimensions of planted area, harvested area, production and land productivity shows the production perspective. The spatial distribution of the local food potentials based on the index calculation (known as Index of Food Relocalisation/IFR) explains the spatial aspect. Previous research identified that the IFR application less considers on local food systems and biophysical discussion (Benedek \& Balázs, 2016). This paper attempts to fill the research gap by adding an agroecology discussion to show the biophysical characteristics of the research area.

Previous researches offered an answer on how to portray local food mainly through spatial analysis through constructing an index. The initial work of local food mapping was conducted by Ricketts Hein, Ilbery, and Kneafsey (2006). Their work resulted in the "Index of Food Relocalisation" (IFR), referring to Paul Knox's formula (Knox, 1974), which is constructed from producing and marketing sub-Index and derived from six indicators (Ricketts Hein et al., 2006). They applied their index in sixty-one counties of England and Wales and showed a different pattern between rural and urban counties, the pattern which showed scores depending on the underlying factors in the particular county such as physical, cultural, tourist and/or economic characteristics. The second previous literature finds the spatial concentration of local food activities by comparing two regions in England (Ilbery, Watts, Simpson, Gilg, \& Little, 2006). Then, the IFR application attracts Watts, Leat, \& Revoredo-Giha (2011) to employ the index in the context of Scotland by using five categories: location, business activities, product designations, membership of industry or cooperative organisations, and the sources in which the enterprise is listed. The latest paper of Benedek and Balázs (2016) develops the IFR or FRI (Food Relocalization Index) in their notion, as a production sub-index into a composite index called "Policy Intervention for Food Relocalization Index (PIFRI)" that are taken in the twenty counties of Hungary.
This paper tries to adopt the index (IFR) in order to study local food aspect in DIY. According to Isma'il, Badan Ketahanan Pangan, and Fakultas Teknologi Pertanian, Universitas Jember (as cited in Suryana, 2016), there are various definition of local food in Indonesia. The official definition is from Law of Food or Undang Undang No 18 Tahun 2012 (Rachmat \& Syakir, 2016; Suryana, 2016). However, some scholars operationally employ different definitions based on used data (Erwidodo, 2016; Suryana, 2016). Because of data availability, it is quite difficult to apply the same variables in the context of DIY as used in the previous studies (Benedek \& Balázs, 2016; Ilbery et al., 2006; Ricketts Hein et al., 2006; Watts et al., 2011). As mentioned in terms of "triple burden" (Gardjito, 2017), in Indonesia, it is difficult to obtain suitable data to analyse local food (Erwidodo, 2016; Suryana, 2016). Suryana (2016) notices difficulties in obtaining any data of plantation and production of local food for his analysis. Fortunately, for the most area of DIY, the BKPP DIY has a local food database. Then the information provided in the database are employed, in which local food is operationally defined as non-rice carbohydrate crops (Khudori, 2008).

This paper uses four aspects of local food production: planted area, harvested area, production amount and land productivity all provided by the BKPP DIY (Badan Ketahanan Pangan dan Penyuluhan Daerah Istimewa Yogyakarta [BKPP DIY], 2012). These four categories of statistic variable are commonly provided in the agricultural statistical publications that are provided by the official agencies of Indonesia government, for example, Statistik Pertanian 2017 (Pusat Data dan Sistem Informasi Pertanian Kementerian Pertanian Republik Indonesia, 2017). From the definition provided by Statistics Indonesia (Badan Pusat Statistik or hereafter BPS) and Ministry of Agriculture of the Republic of Indonesia (Kementerian Pertanian, formerly known as Departemen Pertanian or Deptan), Sanny defines these four aspects (Sanny, 2010): planted area as an area where a particular crop 
is planted, harvested area as an area where a particular crop is harvested, production amount as weight of the yield of the particular crop from the harvested areas, and land productivity as yields of a particular crop per area.

According to the experience of Benedek and Balázs (2016), the IFR gives an advantage of mapping local food and assisting a planning program of the rural inhabitants. However, they also point out two limitations of the IFR particularly concerning the biophysical aspect and the local food system issues (Benedek \& Balázs, 2016). This paper attempts to elaborate the broader method of local food mapping by adding the ZAE analysis as representing the biophysical aspect.

Concerning the agricultural development, the Research and Development Unit of the Ministry of Agriculture provides the map of Zone of Agro-Ecology (ZAE). This map gives two important information: 1) the agricultural zone system based on the regional characteristics and 2) the regionalisation of prospectus commodity crops following the land suitability in order to support agriculture development planning (Sutriadi et al., 2013). In the context of DIY, the map system includes agriculture and non-agriculture zones. According to the agro-ecological zone calculation of Sutriadi et al. (2013), DIY has $91.36 \%$ of the agricultural area and $8.64 \%$ of the non-agricultural area. Following their detail division, the DIY's agricultural zones are categorised into zone II, III and IV, and further grouped into IIIaq, IIIax, IVaq and IVax subzones, implying the suitability for distinct farming activities (Sutriadi et al., 2013). They explain that the IIIaq and the IVaq subzones are suitable for wet paddy, and meanwhile the IIIax subzone is for rubber, coconut, palm oil, robusta coffee, pepper, vanilla, stink bean (petai), starfruit, jackfruit, duku, durian, guava, orange, mangosteen, corn, soybean, green bean, peanuts, cowpea, sweet potato, cassava, banana (Sutriadi et al., 2013). Lastly, the IVax subzone is suitable for dry paddy, corn, green bean, peanuts, cowpea, sweet potato, cassava, tobacco, red onion, palm chilli (Sutriadi et al., 2013).

The National Development Agency (Bappenas) proposes the four concepts of regional development based on: 1) character, 2) spatial or regional planning, 3) integrated development, and 4) cluster development (Setiyanto \& Irawan, 2015). Moreover, for the development goals, Setiyanto and Irawan (2015) deploy the concept of regional agricultural commodity development. If a suitable commodity crop is planted based on the agro-ecological zone system, optimum benefits is expected, increasing the productivity (Sutriadi et al., 2013). For example, arrowroot can be planted in all the agro-ecological zone (Hermansyah, Murniyanto, \& Badami, 2009). However, Hermansyah et al. (2009) argue that it is challenging to develop arrowroot in Madura inland because of no information of its agro-ecology. Another example can be seen in the agroforestry practice in Kulonprogo. Farmers with adaptive ability and knowledge on managing land can take advantages of commodity choices following the local agroecological features (Hani, Indrajaya, Suryanto, \& Budiadi, 2016). Finally, if farmers could optimise their commodity production, it leads to an increase in their income (Simatupang, 2016).

\section{Research Method}

This paper focuses the four regencies in DIY, Indonesia (Figure 1): Sleman, Gunungkidul, Bantul and Kulonprogo. The city of Yogyakarta is not analysed at this time due to no available data at the village (kelurahan) level. This section explains three main stages of the research method: ZAE review, LFI measurement, and SPP (Survei Pendapatan Rumah Tangga Usaha Pertanian) calculation (Figure 2).

The first stage is to review the ZAE map. In the previous part of this paper, it is pointed out that DIY has four sub-zones of agricultural area, namely IIIaq, IIIax, IVaq and IVax. The main purpose of this paper is to find out the spatial concentration of local food and therefore the analysis pays attention to IIIax and 
IVax which show the suitability for annual or food crops and for food crops, respectively, both as commodities including cassava and sweet potato that are representative of DIY's local food crops, comparing to other subzones (IIIaq and IVaq) that are potentially suitable for wet paddy (Sutriadi et al., 2013). Each village is given four classifications: the notion $1,2,3$, or 4 based on the spatial relation to the ZAE system. The notion 1 means that in the villages there is neither subzone IIIax nor IVax. The notion 2 reflects that the villages have the IIIax subzone. The notion 3 means that the villages have the IVax subzone. The notion 4 shows that the villages see both IIIax and IVax subzones in their areas.

To calculate the local food index (LFI) is the second stage of this study. In order to answer the first research question. This paper uses LFI as the index's name rather than Index of Food Relocalisation (IFR) that many previous researches have used, due to the local food parameters that this paper analyses. In total the analysis includes 393 villages: 86 villages in Sleman, 144 villages in Gunungkidul, 75 villages in Bantul and 88 villages in Kulonprogo. The primary data source is the Local Food Database from the BKPP DIY in 2012 (Badan Ketahanan Pangan dan Penyuluhan Daerah Istimewa Yogyakarta [BKPP DIY], 2012). The data source contains four leading indicators of main food crops (Noorjenah et al., 2015): planted area (ha), harvested area (ha), land productivity (Kwintal/ha) and production amount (metric ton).

For Sleman, Gunungkidul, and Bantul, the database gives information of eleven local food crops: cassava, sweet potato, edible canna, arrowroot, prasina, birch rim yam, pumpkin, taro, tuber, breadfruits and elephant's foot. However, for Kulonprogo, the database only provides ten local food crops, excluding taro. In this paper, the values of ten crops that are available in all the regencies are read from the hardcopy of the local food database report, and inputted manually into Microsoft Excel.

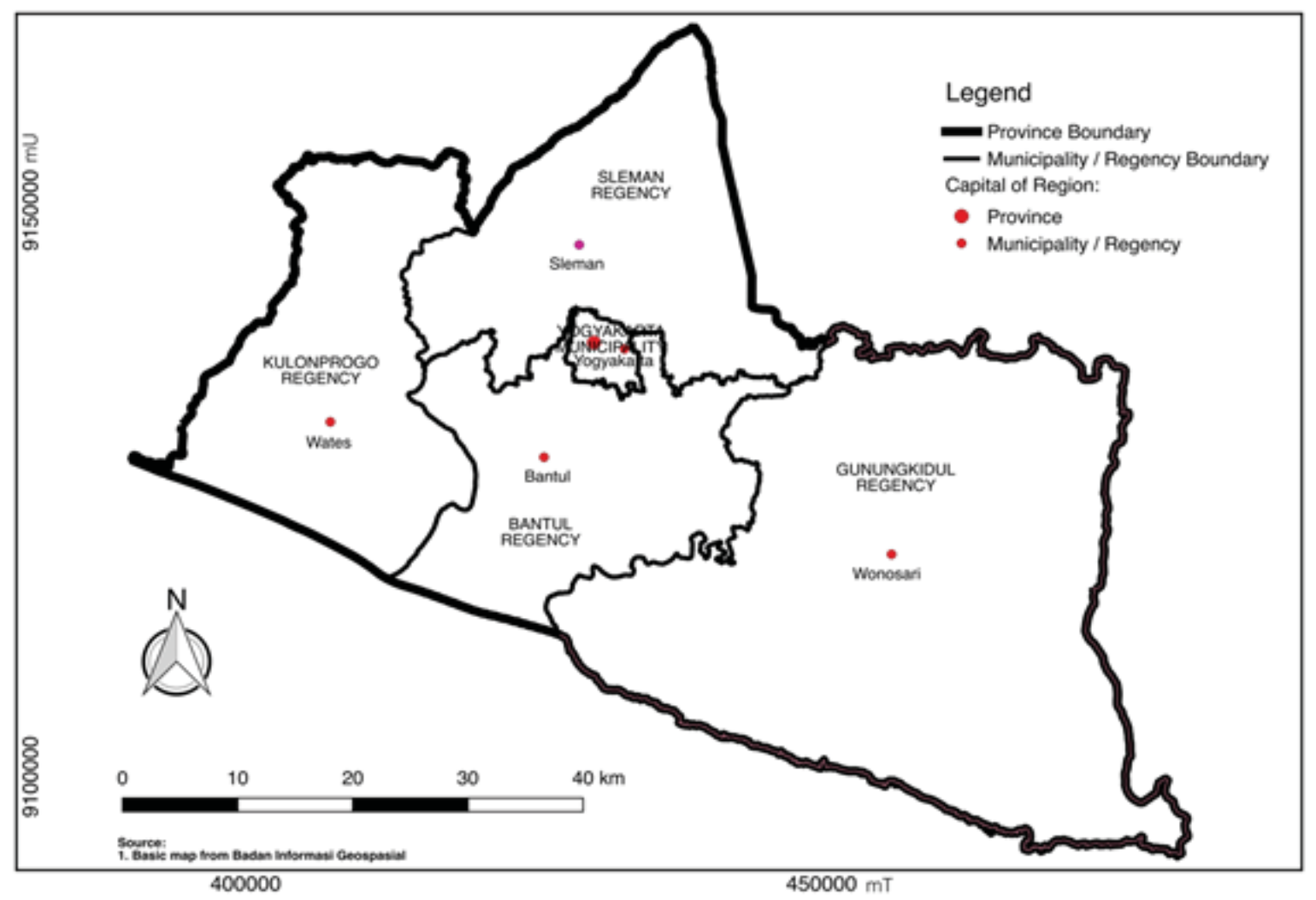

Figure 1. The administrative map of Yogyakarta Special Province (Source of map from Geospatial Information Agency or Badan Informasi Geospasial). 
The IFR formula that Ricketts Hein et al. (2006) first proposed is . showing the sum of each indicator for the village ${ }_{i} \mathrm{~N}$ is the number of indicators and $\mathrm{C}$ is the number of villages in a regency. Less score shows the highest index. In this paper, the IFR formula represents the subIndex. Then, to provide the Local Food Index (LFI), this paper follows the formula of Ricketts Hein et al. (2006), proposing LFI = (sub-index (IFR) A + sub-index (IFR) B + sub-index(IFR) C + sub-index(IFR) D )/4. Alternatively, the LFI formula is .

This paper adopts the index measurement proposed by Knox (1974) but employs different variables that show local food in the local context and which reflect four categories to produce four sub-Index as mentioned above namely: planted area, harvested area, land productivity, and production amount. Following Ricketts Hein et al., all of these four sub-Index results in the Local Food Index ("IFR"). This paper adopts the IFR measurement of Benedek and Balázs (2016) on. Due to the dissimilar availability of the local food indicators in the database as mentioned above, this paper analyses ten indicators in order to provide the maps of local food (potential) index for DIY.

Next, the local food index is drawn into the rank of each village in the study area, using the "rank function" provided in Microsoft Excel. Niels Weterings via his helpful website, www.excel-easy.com, provides detail steps for ranking the data (Easy, n..d). Secondly, after each village gets rank in each indicator value, all the rank from those indicators are summed up for each sub-Index. In other words, the subIndex value is the total rank from all indicator ranks (Rj). Following the explanation of Benedek and Balázs (2016), smaller rank shows better condition in the resulted maps (the subindex and LFI map). Operationally, there are several villages with no data, 152 villages in the study area (B). The treatment for the villages without data or the villages that contain 0 value in the sub-Index maps (Figure 4) is to exclude them from creating the LFI map. So, the highest value for the LFI is seen at the village with 6.40 value. For classification of the villages, rather than following the previous research using the quartile interval (Benedek \& Balázs, 2016; Knox, 1974), in this paper the equal interval is shown following the result of the QGIS calculation of the original measurement (score). The spatial pattern analysis is taken by widening the previous Lyson's (2004) research that focuses on the top ten regional analysis, taking account for the top fifty villages.

The next results are provided by two sets of analysis to answer why the LFI concentrate in those particular regions. The first subsection of analysis is conducted by using a crosstabulation matrix to show the typological correspondence of each quartile of the LFI scores and the agro-ecosystem zones.

A cross-tabulation matrix is a method that usually used to analyse land use change (Cuba, 2015; Nourqolipour et al., 2016; Pontius \& Petrova, 2010; Pontius, Shusas, \& McEachern, 2004). Initially, for the land use change analysis, a cross-tabulation matrix is set the two-time interval (Batisani \& Yarnal, 2009; Pontius et al., 2004; Versace, Ierodiaconou, Stagnitti, \& Hamilton, 2008), using two variables in the row and column in two different periods of land use categories (Pontius et al., 2004; Wang, Cheng, \& Chen, 2011).

In this paper, on the row the variables of the selected ZAE zones are placed. The data of Zone Agro-Ecology (ZAE) map includes four zones and eight sub-zones in detail: Ilaq, IIax, IIbx, IIcx, IIIaq, IIIax, IVaq, and IVax (Sutriadi et al., 2013). Moreover, Sutrialdi et al. (2013) explain that the zones of I-IV are appropriate for forest plantation, annual crops, annual or food crops, and food crops, respectively. Then, the analysis is continued by the map-overlay technique of the DIY village administration and the agro-ecosystem maps, following previous Musyafak's (2015) method in order to gain what percentage of the ZEA zones are in each village. For the ZAE zones, each village is given one of four classifications based on its relation to the two selected sub-zones of the ZAE system (IIIax and IVax), as explaned in the first step of this section. The result is presented in the Table 2. 
The second subsection to analyse the concentration pattern is to identify the income levels resulted from the agricultural activities. There is a question whether economic motives are related to the farmers' choices to plant paddy or palawija (second crop). However, due to the lack of available data, this paper analyses farm households' income from paddy and second cultivated crops at the subdistrict (kecamatan) level not at the village level. The data are derived from the Income Survey from Households' Agricultural activities or Survey Pendapatan Rumahtangga Usaha Pertanian 2013 (SPP 2013) of the BPS (Badan Pusat Statistik [BPS], 2013). Two kinds of the average income are available: one from wet and dry paddy cultivation and the other from second commodity crops, including: maize, soybeans, peanuts, green beans, cassava, sweet potato, sorghum, taro, edible canna (ganyong), and arrowroot (irut). There are 6035 selected households as the sample, consisted of 1303 households in Kulonprogo, 1531 households in Bantul, 1780 households in Gunungkidul, and 1421 households in Sleman, respectively. In order to obtain information of the average household income this paper follows the previous research of Firani (2011) that provide a formula to calculate the average total income in a particular region (sub-district). Then, the classes of average income (from very high to very low) are identified for each sub-district, and drawn into the map. This map is again spatially based on the data of sub-districts at the one-level higher than a village (desa) in the Indonesia administrative structure. Therefore, this paper tries to identify the spatial pattern and then to give descriptions. To sum up, the research process is presented in a research diagram below (Figure 2).

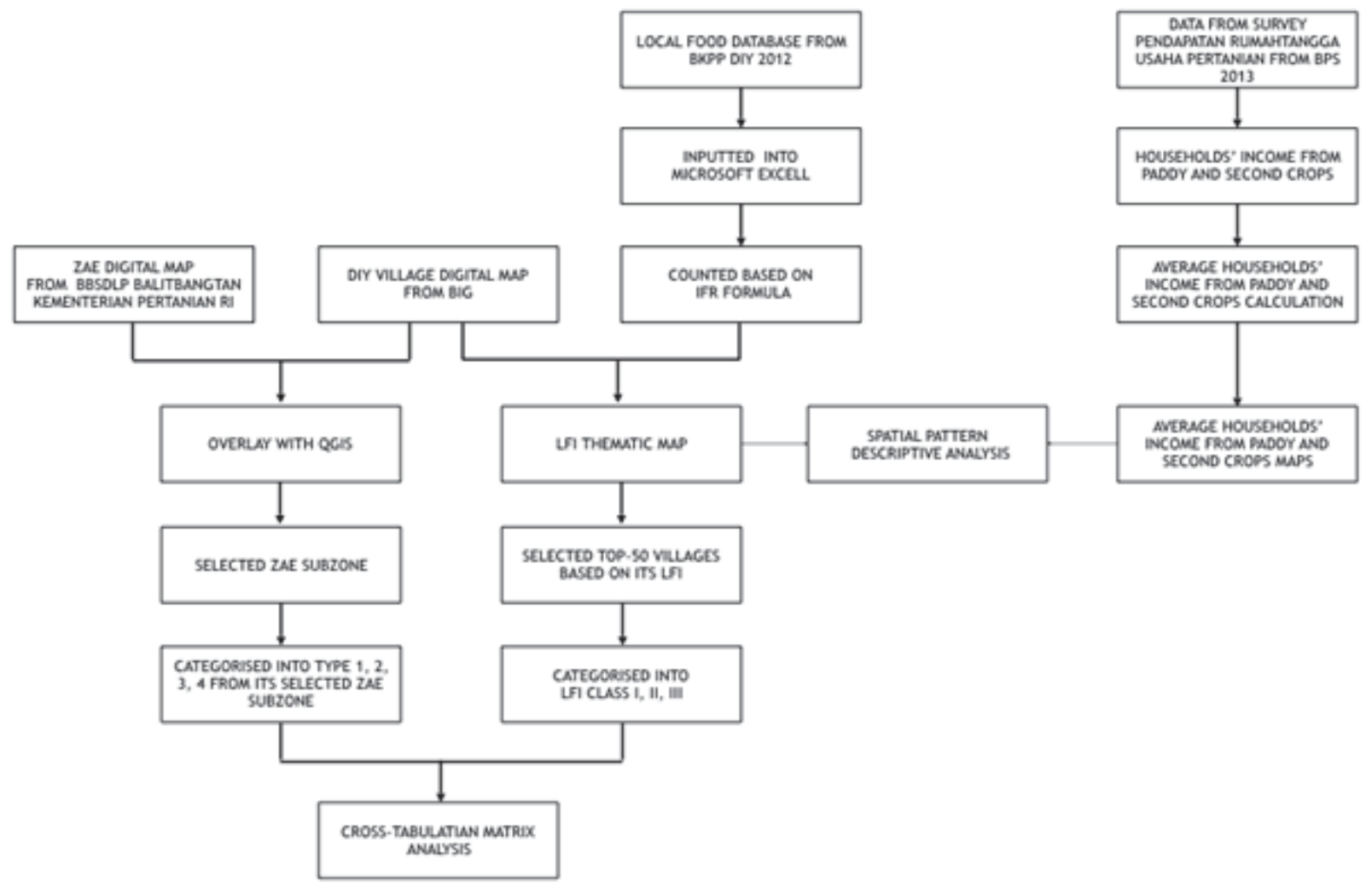

Figure 2. Research Diagram 


\section{Results and Discussion}

\subsection{Results}

The landscape of agro-ecologies in DIY are grouped into agriculture and non-agriculture zones (Sutriadi et al., 2013). The IIIax and IVax sub-zones, representing the perennial and food crops, are mainly concentrated in the middle part of Gunungkidul regency, some seen dispersedly in the north part of Sleman and the western part of Kulonprogo regencies. Meanwhile, the IIIaq sub-zone, indicated by the green colour, is suitable for wet paddy commodity and concentrates in Kota Yogyakarta, some part of Sleman and Bantul regencies, and some area at the southern part of Kulonprogo. .

The local food index is composed of the maps of the four sub-index (Figure 4). The villages with very high and high scores (indicated by the darker green colour) in terms of the planted area sub-index (Figure 4A) are distributed in all the regencies, but ones of very high score are concentrated in two regencies: Gunungkidul and Kulonprogo regencies. Meanwhile, in Gunungkidul, the very high and high scored villages are concentrated in the northern and south-eastern part of Wonosari (the capital of Gunungkidul), while in Bantul, the villages with a relatively very high and high score of this sub-index are distributed in the eastern and western part, adjacent to other neighbouring regencies: Gunungkidul and Kulonprogo. In Kulonprogo, the very high and high scored villages are located in the northern and south-eastern part of the Wates (the capital of Kulonprogo). Finally, in Sleman there are only two villages adjacent to Bantul and Gunungkidul regencies.

The spatial pattern of the harvested area of local food sub-index (Figure 4B) is almost similar to that of the planted area sub-index. The very high scored villages of this sub-index are located in Gunungkidul and Kulonprogo regencies, while the high scored villages are distributed mostly in Gunungkidul, followed by Kulonprogo, Bantul and Sleman. Comparing to the map of the planted area sub-index, there is an additional one village with a very high score in Kulonprogo.

The production amount of local food subindex (Figure 4C) shows that the very high scored villages are distributed in Gunungkidul and Kulonprogo regencies. The high score of this sub-index is seen widely in Kulonprogo, Gunungkidul and Bantul. In Gunungkidul, the villages with very high and high scores are found in the northern part. Meanwhile, in Kulonprogo, the villages with comparative advantages for production amount of local food are found in the eastern and western part. Lastly, for Bantul the high score of this subindex shows that the villages are located in the north-western part.

The land productivity of local food sub-index (Figure 4D) depicts that the very high scored villages are distributed only in Kulonprogo, while the high score of the subindex is seen in Gunungkidul and Kulonprogo regencies. In Kulonprogo, the villages with high land productivity are located mainly in the western part and some in the south-eastern part of Wates. In Gunungkidul, the villages with high sub-index score are found in the northern part.

Finally, for the local food index (LFI) in DIY (B), there is only one village in Gunungkidul with its very high score, while for the high scored villages are located in Gunungkidul and Kulonprogo. To sum up, this paper finds that only in two regencies, Gunungkidul and Kulonprogo, as the local food potential compares to others regencies in DIY. In Gunungkidul, the villages that have very high and high scores of the LFI are located in the northern and south-eastern part of Wonosari. In Kulonprogo, the villages with high score of the LFI are found in north-western and southeastern part of Wates. For Bantul, the villages with high LFI are found in the northwestern and north-eastern parts from Bantul (the capital of the regency). Information explaining agroecology subzone can be seen in Table 1 . 
Table 1. Information explaining agroecology subzone (appendix for Figure 3):

\begin{tabular}{|c|c|c|}
\hline Zone/ Subzone & System & Sub system \\
\hline I & Forestry crops & Non-agricultural crops \\
\hline IIaq & Perennial crops & $\begin{array}{l}\text { Perennial crops dryland } \\
\text { Lowland wet climates }\end{array}$ \\
\hline IIax & Perennial crops & $\begin{array}{l}\text { Perennial crops dryland } \\
\text { Lowland wet climates }\end{array}$ \\
\hline IIbx & Perennial crops & $\begin{array}{l}\text { Perennial crops dryland } \\
\text { Medium land wet climates }\end{array}$ \\
\hline IIcx & Perennial crops & $\begin{array}{l}\text { Perennial crops dryland } \\
\text { Highland wet climates }\end{array}$ \\
\hline IIIaq & Annual crops/ Food crops & $\begin{array}{l}\text { Annual crops/ Food crops } \\
\text { Wetland lowland wet climates }\end{array}$ \\
\hline IIIax & $\begin{array}{l}\text { Annual or Perennial crops/ Food } \\
\text { crops }\end{array}$ & $\begin{array}{l}\text { Annual or Perennial crops/ } \\
\text { Food crops dryland lowland wet } \\
\text { climates }\end{array}$ \\
\hline IVaq & Food crops & $\begin{array}{l}\text { Food crops wetland lowland wet } \\
\text { climates }\end{array}$ \\
\hline Ivax & Food crops & $\begin{array}{l}\text { Food crops dryland lowland wet } \\
\text { climates }\end{array}$ \\
\hline X3 & & \\
\hline
\end{tabular}

Source: translated from Sutriadi et al. (2013, p. 17)

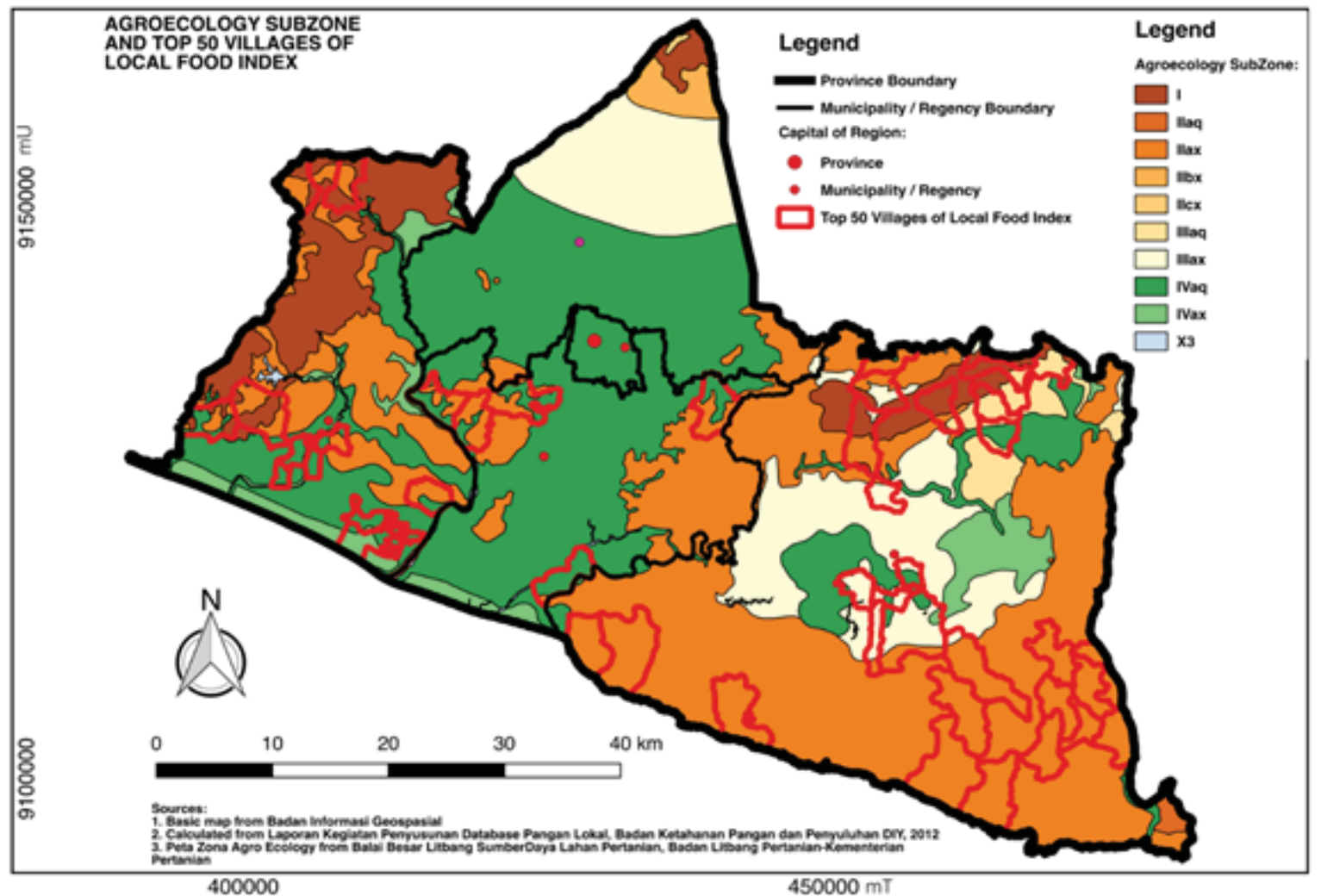

Figure 3. Local Food Index and Agroecology Condition in Yogyakarta Special Province. 


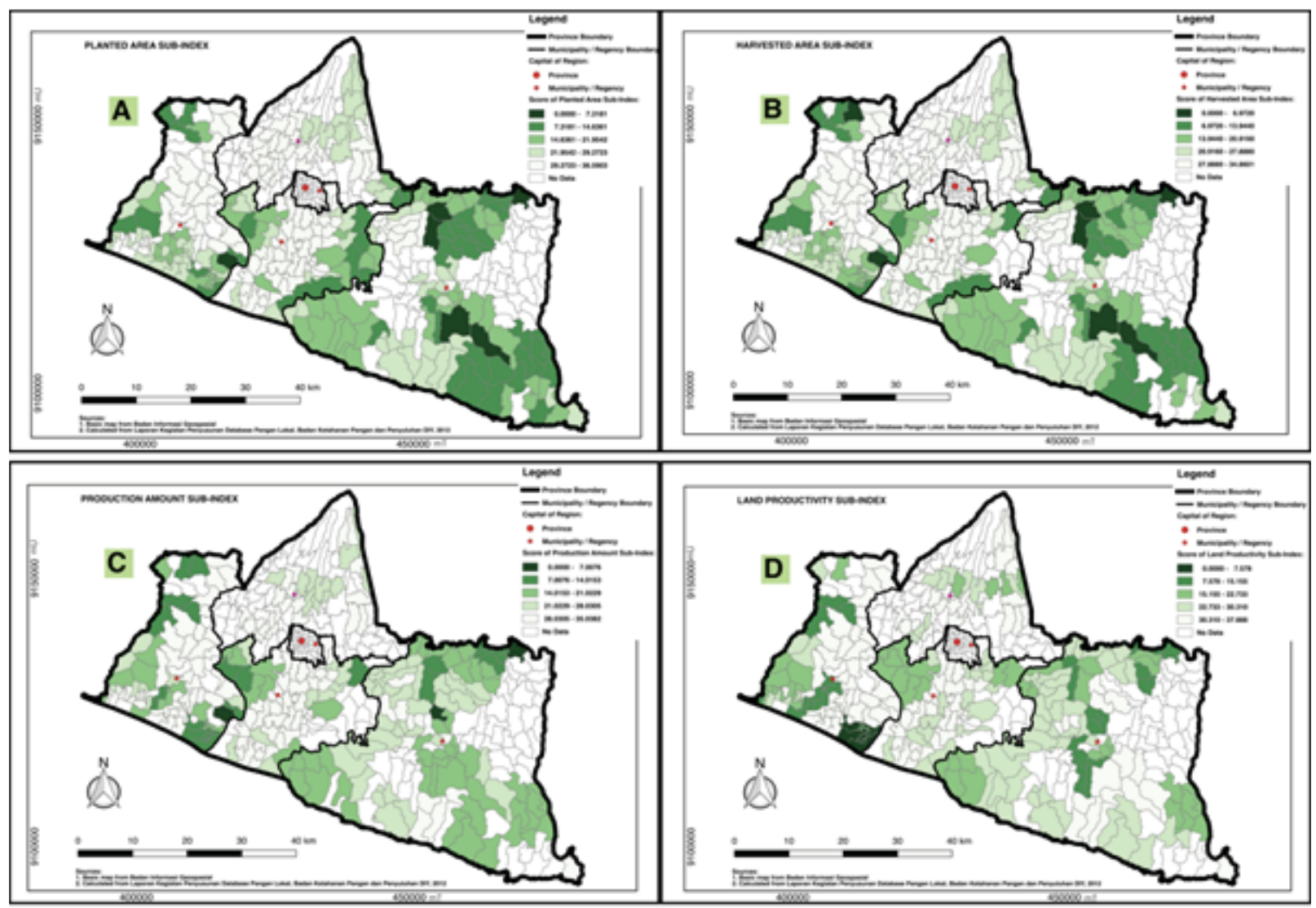

Figure 4. Local Food Sub-Index. 4A. Planted Area Sub-Index, 4B. Harvested Area Sub-Index, 4C. Production Amount Sub-Index, 4D. Land Productivity Sub-Index..

Table 2. The cross-tabulation of top 50 villages based on the LFI scores and the selected sub-zones of the ZAE

\begin{tabular}{|c|c|c|c|c|c|c|c|c|c|c|c|c|c|}
\hline \multirow{2}{*}{$\begin{array}{c}\text { ZAE } \\
\text { LFI }\end{array}$} & & 1 & & & 2 & sys & & 3 & & & 4 & & \multirow{2}{*}{ TOTAL } \\
\hline & KP & B & GK & KP & B & GK & $\mathbf{K P}$ & B & GK & $\mathbf{K P}$ & B & GK & \\
\hline I & & & 1 & & & & & & & & & & 1 \\
\hline II & 2 & 2 & 7 & & & 6 & 5 & & & & & 1 & 23 \\
\hline III & 5 & 3 & 11 & 1 & & 4 & 2 & & & & & & 26 \\
\hline TOTAL & 7 & 5 & 19 & 1 & & 10 & 7 & & & & & 1 & 50 \\
\hline
\end{tabular}

Source: the author's analysis from the LFI calculation and the ZAE map. Note of abbreviation: KP = Kulonprogo, B = Bantul, GK=Gunungkidul

Table 2 shows the distribution of the top 50 villages based on the LFI scores and the selected two sub-zones of the agro-ecological system. They are distributed in three regencies: Gunungkidul, Kulonprogo and Bantul. There is only one village with very high score of the LFI (Class I), and twenty-three villages with high score of the LFI (Class II). Finally, the average score of the LFI (Class III) is supported by twenty-six villages. Meanwhile, the type 1 of the ZAE is supported by 31 villages, while the type s 2, 3 and 4 are supported by 11, 7, and one villages, respectively. It can be argued that most the villages (more than half) are located in the areas where are not suitable for cassava and sweet potato (Type 1 of the ZAE). Meanwhile, for Types 2 and 311 and 7 villages are located in the area with perennial and food crops, and food crops, respectively, both in low dryland and wet climate. Lastly, for Type 4 that represent the combination of the IIIax and IVax of the ZAE sub-zones is supported 
by one village. From Table 2, this study finds discussing section, particularly to answer why that the local food is not necessarily located most the local-food producing villages are in the suitable area in terms of the local agro- located not in the suitable area.

ecologies. Further discussion is needed in the
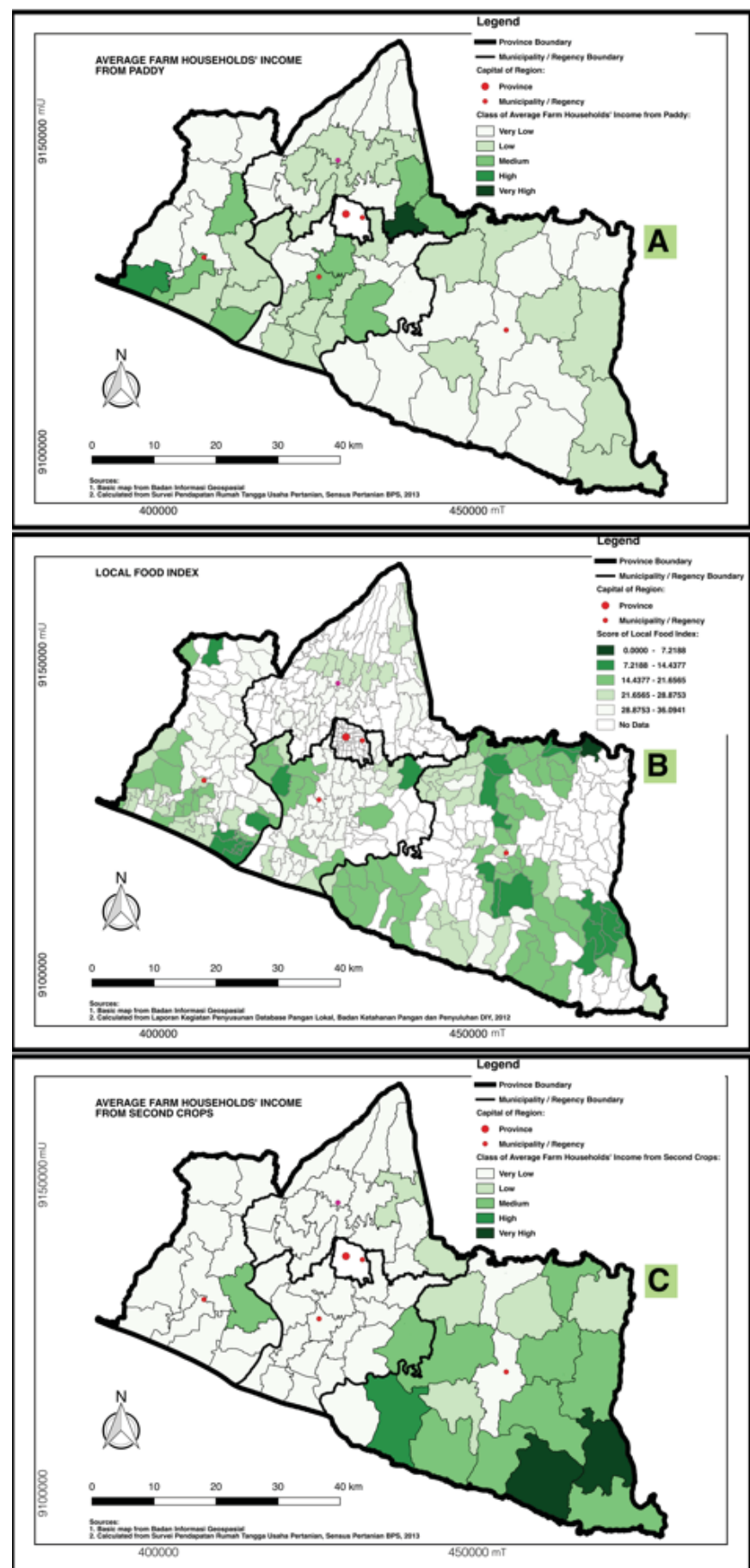

Figure 5. (A) Average Farm Households' Income from Paddy, (B) Local Food Index, and (C) Average Farm Households' Income from Second Crops. 
As for relations between the spatial patterns of the LFI and farm households' income levels, from can identify some findings that the sub-districts of very high and high average income from paddy are concentrated in Sleman and Kulonprogo regencies (A). In Sleman, the paddy income level is very high found in the sub-districts located in the south-eastern part of Sleman (the capital of the Sleman regency). Meanwhile, in Kulonprogo, the high average income is found in one sub-district located in the southwestern part of Wates. In contrast, the very high and high average income from secondary crops (C) is spatially distributed mainly around the south-eastern part of Wonosari in Gunungkidul, while the high average income is seen in the south-western part. The next section discusses the relations of the income level, the LFI and the ZAE.

\subsection{Discussion}

Before entering the discussion section, firstly this paper returns to the first research question: Where are the local food potentials seen in DIY? To sum up the results, the composite index (LFI) shows that Gunungkidul and Kulonprogo are two regencies in DIY that have relatively higher local food potentials. Most the highly potent villages are concentrated in the rural areas, relatively distant from the urban area of Yogyakarta (the city of Yogyakarta and its surrounding area). This pattern is in line with the previous literature mainly from the western countries showing that the local food activities are concentrated in the rural areas (Ilbery et al., 2006). However, in DIY context, the reasons why this spatial pattern emerge seems different, considering the regional geographical characteristics.

According to Rijanta and Rotgé (2000), Sleman and Bantul regencies include the most suitable place to grow rice, also mentioning farmers' practices agroforestry in Gunungkidul. Meanwhile, in Kulonprogo that has both lowland and upland areas, three crops of rice, fruits, and vegetables are main commodities.

Gunungkidul, where the local food potentials are found in this study, was previously a critically underdeveloped region (Proyek Penelitian dan Pencatatan Kebudayaan Daerah, 1978) and it was estimated in the 1940s and 1950s possible to plant only tea or coffee (Whitten, Soeriaatmadja, \& Afiff, 2000). However, after the government introduced the regreening program in the mid-1970s to the mid-1980s (Maryudi et al., 2015; Soerianegara \& Mansuri, 1994) the landscape in Gunungkidul had drastically changed. This program succeeded in greening the formerly critical areas, and the local inhabitants could have other choices for their livelihoods: for example, to plant trees or utilise food crops (Maryudi et al., 2015; Soerianegara \& Mansuri, 1994).

There is another question: why the local food potential is concentrated in these particular areas? Based on not only indexbased descriptions but also on an extended explanation, it is possible to consider some factors contributing to shaping the patterns of the local food potentials, such as: 1) physical support, represented by the ZAE, and 2) economic motive represented by the income level.

This paper found that more than half of the selected top 50 villages in the LFI are located not in the suitable area for the local food production. Several reasons can probably be called into account. Firstly, it is possible for farmers to tend to expect main staple foods such as rice suitable for the local geographies rather than local food crops to gain their income (Mardianto \& Djauhari, 2015). But, secondly, local food is sometimes planted as an intermittent crop in the paddy fields, using the rotation scheme: rice-rice-second crops, or the mixed cultivation of taro (talas) in private forests, and cassava using intercropping technique to take care of ecological conditions for farming, to disperse possible risks and to double gains (Pearson, Falcon, \& Jones, 1984; Roche, 1984; Sudomo \& Hani, 2014; Sumaryanto, 2004).

As for a more economic factor, Sumaryanto (2004) attempts to compare the average income received by paddy farmers in the same agroecosystem area in Brantas catchment area (DAS Brantas) in East Java, Indonesia 
and previous researches of PATANAS. According to Yusdja (1984) PATANAS is Panel Petani Nasional or National Farmers' Panel. Sumaryanto found that the household agricultural income in DAS Brantas was higher compare to PATANAS because of different households sample unit and different farming productivity. Inspired by Sumaryanto's research, based on $\mathrm{B}$ and $5 \mathrm{C}$, a similarity pattern analysis can identify that the scores of the LFI are spatially almost in line with the income levels. Comparing the average income from paddy (A) and the ZAE map (Figure 3), there is a spatially similar pattern that the very high and high average incomes from paddy are mostly seen in the subzone IVaq: wet paddy suggested area. In other words, this area is the most favoured place to grow paddy according to Rijanta and Rotgé (2000).

In contrast, the average income from secondary crops (C) spatially corresponding to the suitable ZAE subzones is supported by the practice of agroforestry in Gunungkidul and Kulonprogo (Hani et al., 2016; Nibbering, 1999; Rijanta \& Rotgé, 2000; Ritohardoyo \& Prakosa, 2002). Through agroforestry, for example, the people in Gunungkidul have options to fulfil their livelihoods by selling forestry and/or farming products in the forests (Nibbering, 1999). Titisari and Setyawan (2018) provide an evidence in TRUBUS magazine, reporting the two farmers in Gunungkidul who plant local food (iles iles) in their cacao home gardens using a polyculture technique. Another practice is also found, for example in general cassava is planted using intercropping technique alongside with perennial crops (Roche, 1984).

The agroforestry practices in Kulonprogo are reported also by Hani et al. (2016). According to their fieldworks, cassava is planted under the sengon, clove and cacao tree, their results being essential to local inhabitants livelihood, and local inhabitants attain daily income as a tempeh producer, and monthly and annual income derived from the perennial yields: cacao and clove (Hani et al., 2016). This information probably can explain why the nonfood crops subzone (Type 1) relatively show very high and high income comparing to other ZAE types (Types 2, 3, and 4).

Before closing this discussion, it is necessary to return the "hidden potential" issue proposed in this paper. This study identifies the particular places as a concentration of local food potentials. People can receive benefit for the nutrition and health by consuming local food (Mardiharini, 2016). Farmers can receive a double benefit for their economic lifestyle from their trade activities in addition to self-subsistence (Falcon, Jones, \& Pearson, 1984; Nelson, 1984). Indeed, local food crops are produced widely in rural DIY, and they potentially give an opportunity as a food stock, expecting to tackle food crisis or food insecurity in some, particularly in poor villages in DIY (Widiyanto, 2018). If local food crops are processed into other forms of commodities, they lead to a value-added product, such as flour (Munarso, 2016).

Moreover, as for flour for example, Munarso (2016) explains the multiplier effect through three scales of industry: 1) home industry, 2) agro-industry, and 3) mix-flour industry (mixture of local and wheat flour). One example is about a modified cassava flour (mocaf). Since developed in 2015, now mocaf is widely distributed not only in Java but also in Papua, South Kalimantan, and Gorontalo (Vebriansyah, Setyawan, Ramadhan, \& Pratiwi, 2018). Local households, communities or community-based organizations, and largerscale industries probably receive an advantage from such processed local food (Vebriansyah et al., 2018). Meanwhile, although currently the spatially concentrating production of local food crops is potentially hidden, and how to ship and market local food commodities is not clearly discussed in this paper, it possibly brings about severe competitions among such producing places, leading to increased production in a particular place and declined production in the other place.

\section{Conclusion}

This study finds out that there are two local food potential regencies in DIY: Gunungkidul 
and Kulonprogo. Considering the agroecological factor in order to discuss why such concentrations emerge in those regencies, this paper identifies two reasons why most the actively producing villages are not located in the 'hypothetical zone'. Firstly, local food crops are able to be grown in various agroecological environments, and secondly the farmers often practice intercropping cultivation on paddy and agro-forestry fields. The average income approach also shows the correspondence of spatial patterns between the income levels and the LFI scores.

It is expected that, after the local food potential in DIY are mapped out, the hidden local food potentials are found. This kind of information is useful as a supporting tool to anticipate tackling food crisis that is predicted in 2037 by the BKPP DIY (Kedaulatan Rakyat, 2017), for example by indicating the particular villages that can be promoted as the potential pockets of local food production. Indirectly, the findings from this study is also useful to provide information about how the "hidden potential" of local food are explored, ranging from nutrition and health to various livelihood impacts that are received by the stakeholders' local food practices.

Finally, this paper has provided a methodological foundation on local food study from the geographical perspective, attempting to map out the hidden local food potentials. However, this paper identifies some limitations. Firstly, the index explained in this paper seem only to give general information. A detail explanation is still needed, particularly on analysing the local food crops. In particular, this paper focuses just ten local food crops. However, a variety of other local food crops are necessary to be incorporated into the local food index (LFI), almost neglected in the analysis.
Further researches are needed to address these issues. For instance, an alternative method such as Location Quotient (LQ) devised in a previous research (Watts et al., 2011) probably can give a contribution to the analysis of local food potentials from a different quantitative perspective. Secondly, this paper only provides an analysis of physical and economic factors. Other possible factors are needed to explore deeply and enrich the geographical studies and also other disciplines interested in local food. Thirdly, this study only pays attention to the first and second aspects of the "triple burden" theory of local food that is proposed by Professor Moerdijati Gardjito. There remains one issue unanswered in this paper: the policy matter. Therefore, there are potentially future researches exploring to what extent of the local food policy are delivered in DIY.

\section{Acknowledgement}

The author, would like to thank the Ministry of Research, Technology and Higher Education and the Ministry of Finance for the BUDI LN scholarship managed by LPDP for their support. The author would like also thank Professor Makoto Takahashi and Associate Professor Masaya Iga for their valuable inputs, suggestions on preparing and finishing this paper. The author would like thank to Professor Moerdijati Gardjito for her hospitality and kindness on teaching valuable information regarding local food themes to the author. Finally, the author would like to thank BKPP DIY for the local food database, BPS for the average income data, Badan Informasi Geospasial and Balai Besar Litbang SumberDaya Lahan Pertanian- Badan Litbang Pertanian Kementerian Pertanian for their digital maps.

\section{References}

Badan Ketahanan Pangan dan Penyuluhan Daerah Istimewa Yogyakarta [BKPP DIY]. (2012). Laporan kegiatan penyusunan database pangan lokal. Retrieved from Yogyakarta: Badan Ketahanan Pangan dan Penyuluhan Daerah Istimewa Yogyakarta

Badan Pusat Statistik [BPS]. (2013). Sensus Pertanian 2013, Survey Pendapatan Rumah Tangga Usaha 
Pertanian, Pedoman Pencacah (ST 2013-SPP.PCS) Jakarta: Badan Pusat Statistik.

Batisani, N., \& Yarnal, B. (2009). Urban expansion in Centre County, Pennsylvania: Spatial dynamics and landscape transformations. Applied Geography, 29(2), 235-249. doi:https://doi. org/10.1016/j.apgeog.2008.08.007

Benedek, Z., \& Balázs, B. (2016). Current status and future prospect of local food production in Hungary: a spatial analysis. European Planning Studies, 24(3), 607-624. doi:10.1080/0965431 3.2015.1096325

Cuba, N. (2015). Research note: Sankey diagrams for visualizing land cover dynamics. Landscape and Urban Planning, 139, 163-167. doi:https:/ / doi.org/10.1016/j.landurbplan.2015.03.010

Easy, E. (n..d). Rank. Retrieved from https:/ / www.excel-easy.com/ examples/rank.html

Erwidodo. (2016). Meningkatkan ketersediaan dan keterjangkauan pangan lokal menuju ketahanan pangan dan nutrisi. In E. Pasandaran, R. Heriawan, \& M. Syakir (Eds.), Pangan lokal: Budaya, potensi dan prospek pengembangan (pp. 329-356). Jakarta: IAARD Press.

Falcon, W. P., Jones, W. O., \& Pearson, S. R. (1984). Cassava's role in food policy. In W. P. Falcon, W. O. Jones, S. R. Pearson, J. A. Dixon, G. C. Nelson, F. C. Roche, \& L. J. Unnevehr (Eds.), The cassava economy of Java (pp. 163-181). Stanford, California: Stanford University Press.

Firani, S. D. (2011). Analisis pendapatan rumah tangga petani hutan rakyat (Studi kasus di Desa Padasari, Kecamatan Cimalaka, Kabupaten Sumedang, Jawa Barat). (Undergraduate), Institut Pertanian Bogor, Bogor.

Gardjito, M. (2017, 30 October 2017) /Interviewer: D. Widiyanto.

Gardjito, M., Djuwardi, A., \& Harmayani, E. (2013). Pangan nusantara: Karakteristik dan prospek untuk percepatan diversifikasi pangan. Jakarta: Kencana.

Hani, A., Indrajaya, Y., Suryanto, P., \& Budiadi, B. (2016). Dry land agroforestry practices in Menoreh Hills, Kulonprogo. Agrivita, 38(2), 193-203.

Hermansyah, Murniyanto, E., \& Badami, K. (2009). Karakteristik agroekologi garut (Marantha arundinaceae L.) Pulau Madura. Agrovigor(Vol 2, No 2 (2009): September), 59-66.

Ilbery, B., Watts, D., Simpson, S., Gilg, A., \& Little, J. (2006). Mapping local foods: evidence from two English regions. British Food Journal, 108(3), 213-225. doi:10.1108/00070700610651034

Jhamtani, H. (2008). Lumbung pangan: Menata ulang kebijakan pangan. Yogyakarta: InsistPress.

Kedaulatan Rakyat. (2017, 8 September 2017). Perlu diversifikasi pangan lokal; 2037, DIY terancam krisis pangan. Kedaulatan Rakyat, p. 9.

Khudori. (2008). Ironi negeri beras. Yogyakarta: INSISTPress.

Knox, P. L. (1974). Spatial variations in level of living in England and Wales in 1961. Transactions of the Institute of British Geographers(62), 1-24. doi:10.2307/621513

Kompas. (2018, 27 February 2018). Keragaman pangan diabaikan. Kompas, p. 1 \& 15.

Lyson, T. A. (2004). Civic agriculture: Reconnecting farm, food, and community. Medford, MA: Tufts University Press.

Mardianto, S., \& Djauhari, A. (2015). Pendekatan pembangunan pertanian berbasis komoditas vs ekoregion: Upaya mencari jalan tengah. In E. Pasandaran, D. Nursyamsi, K. Suradisastra, S. Mardianto, \& Haryono (Eds.), Pembangunan pertanian berbasis ekoregion (pp. 203-222). Jakarta: IAARD Press.

Mardiharini, M. (2016). Pengembangan pangan lokal melalui pemanfaatan pekarangan. In E. Pa- 
sandaran, R. Heriawan, \& M. Syakir (Eds.), Pangan lokal: Budaya, potensi dan prospek pengembangan (pp. 554-568). Jakarta: IAARD Press.

Maryudi, A., Nawir, A. A., Permadi, D. B., Purwanto, R. H., Pratiwi, D., Syofi'i, A., \& Sumardamto, P. (2015). Complex regulatory frameworks governing private smallholder tree plantations in Gunungkidul District, Indonesia. Forest Policy and Economics, 59, 1-6. doi:https:// doi.org/10.1016/j.forpol.2015.05.010

Munarso, S. J. (2016). Perspektif pengembangan teknologi pengolahan pangan lokal. In E. Pasandaran, R. Heriawan, \& M. Syakir (Eds.), Pangan lokal: Budaya, potensi dan prospek pengembangan (pp. 357-373). Jakarta: IAARD Press.

Mustika, I. K. S., Sunartono, \& Saraswati, B. D. (2017, 16 October 2017). Jangan terus tergantung beras. Harian Jogja, p. $1 \& 8$.

Musyafak, A. (2015). Mapping agroekosistem dan sosial ekonomi untuk pembangunan pertanian perbatasan Bengkayang-Serawak Kalimantan Barat. Yogyakarta: Deepublish.

Nawiyanto, S. (2003). Agricultural development in a frontier region of Java: Besuki, 1870 - early 1990s. Yogyakarta: Galang Press.

Nelson, G. C. (1984). Gaplek. In W. P. Falcon, W. O. Jones, S. R. Pearson, J. A. Dixon, G. C. Nelson, F. C. Roche, \& L. J. Unnevehr (Eds.), The cassava economy of Java (pp. 110-135). Stanford, California: Stanford University Press.

Nibbering, J. W. (1999). Tree planting on deforested farmlands, Sewu Hills, Java, Indonesia: Impact of economic and institutional changes. Agroforestry Systems, 46(1), 65-82. doi:10.1023/A:1006202911928

Noorjenah, Subagya, E. H., Iswadi, Amalia, R. R., Siagian, S. H., Poerwaningsih, R., . . . Anggraeny, R. (2015). Produksi tanaman pangan, 2014 (S. H. Hardjo \& Kadarmanto Eds.). Jakarta: Badan Pusat Statistik.

Nourqolipour, R., Shariff, A. R. B. M., Balasundram, S. K., Ahmad, N. B., Sood, A. M., \& Buyong, T. (2016). Predicting the effects of urban development on land transition and spatial patterns of land use in Western Peninsular Malaysia. Applied Spatial Analysis and Policy, 9(1), 1-19. doi:10.1007/s12061-014-9128-9

Pearson, S. R., Falcon, W. P., \& Jones, W. O. (1984). Cassava and Java. In W. P. Falcon, W. O. Jones, S. R. Pearson, J. A. Dixon, G. C. Nelson, F. C. Roche, \& L. J. Unnevehr (Eds.), The cassava economy of Java (pp. 1-7). Stanford, California: Stanford University Press.

Pontius, R. G., \& Petrova, S. H. (2010). Assessing a predictive model of land change using uncertain data. Environmental Modelling \& Software, 25(3), 299-309. doi:https:// doi.org/10.1016/j. envsoft.2009.09.005

Pontius, R. G., Shusas, E., \& McEachern, M. (2004). Detecting important categorical land changes while accounting for persistence. Agriculture, Ecosystems \& Environment, 101(2), 251-268. doi:https:/ / doi.org/10.1016/j.agee.2003.09.008

Proyek Penelitian dan Pencatatan Kebudayaan Daerah. (1978). Geografi budaya daerah Istimewa Yogyakarta. Jakarta: Departemen Pendidikan dan Kebudayaan Proyek Penerbitan Buku Bacaan dan Sastra Indonesia dan Daerah.

Pusat Data dan Sistem Informasi Pertanian Kementerian Pertanian Republik Indonesia. (2017). Statistik Pertanian 2017 (Agricultural Statistics)

Rachmat, M., \& Syakir, M. (2016). Kebijakan pengembangan diversifikasi pangan dan pangan 
lokal. In E. Pasandaran, R. Heriawan, \& M. Syakir (Eds.), Pangan lokal: Budaya, potensi dan prospek pengembangan (pp. 519-538). Jakarta: IAARD Press.

Rahardjo, N., \& Ritohardoyo, S. (2002). Hampiran regional inventory untuk prakiraan luasan tanaman padi di Daerah Istimewa Yogyakarta (Approach of regional inventory for estimating of rice planting area in Yogyakarta Special Region). Forum Geografi, 16(2), 121-133.

Reid, N., Gatrell, J. D., \& Ross, P. S. (2012/2016a). Local food systems and old industrial regions. In N. Reid, J. D. Gatrell, \& P. S. Ross (Eds.), Local food systems in old industrial regions: Concepts, spatial contexts, and local practices (pp. 1-5). Oxfordshire, OX: Routledge.

Reid, N., Gatrell, J. D., \& Ross, P. S. (2012/2016b). Toward a relational geography of local food systems: Or wicked food problems without quick spatial fixes. In N. Reid, J. D. Gatrell, \& P. S. Ross (Eds.), Local food systems in old industrial regions: Concepts, spatial context, and local practices (pp. 251-260). Oxfordshire, OX: Routledge.

Ricketts Hein, J., Ilbery, B., \& Kneafsey, M. (2006). Distribution of local food activity in England and Wales: An index of food relocalization. Regional Studies, 40(3), 289-301. doi:10.1080/00343400600631533

Rijanta, R., \& Rotgé, V. (2000). Geographical features of the region. In V. L. Rotgé (Ed.), Rural-urban integration in Java: Consequences for regional development and employment (pp. 11-20). Aldershot: Ashgate.

Rijanta, R., Widiyanto, D., Toekidjo, T., \& Sulistyani, S. (2013). Factors constraining local food crop production in Indonesia: Experiences from Kulonprogo Regency, Yogyakarta Special Province. Romanian Review of Regional Studies, 9(1), 99-108.

Ritohardoyo, S., \& Prakosa, B. S. E. (2002). Peran serta masyarakat dalam penghijauan: Kasus Kabupaten Gunungkidul Daerah Istimewa Yogyakarta (Popular participation on reforestation: A case in Gunungkidul District Yogyakarta Special Region). Forum Geografi, 16(2), 156-175.

Roche, F. C. (1984). Production systems. In W. P. Falcon, W. O. Jones, S. R. Pearson, J. A. Dixon, G. C. Nelson, F. C. Roche, \& L. J. Unnevehr (Eds.), The cassava economy of Java (pp. 8-62). Stanford, California: Stanford University Press.

Rotgé, V. (2000). Preface. In V. L. Rotgé (Ed.), Rural-urban integration in Java: Consequences for regional development and employment (pp. xvii-xxiv). Aldershot: Ashgate.

Sanny, L. (2010). Analisis produksi beras di Indonesia. BINUS BUSINESS REVIEW, 1(1), 245 - 251.

Setiyanto, A., \& Irawan, B. (2015). Pembangunan berbasis wilayah: Dasar teori, konsep operasional dan implementasinya di sektor pertanian. In E. Pasandaran, D. Nursyamsi, K. Suradisastra, S. Mardianto, \& Haryono (Eds.), Pembangunan pertanian berbasis ekoregion (pp. 62-82). Jakarta: IAARD Press.

Simatupang, P. (2016). Restorasi budaya pangan nusantara sebagai penopang kedaulatan pangan nasional. In E. Pasandaran, R. Heriawan, \& M. Syakir (Eds.), Pangan lokal: Budaya, potensi dan prospek pengembangan (pp. 11-36). Jakarta: IAARD Press.

Soerianegara, I., \& Mansuri. (1994). Factors which determine the success of regreening in Gunung Kidul, Central Java. Journal of Tropical Forest Science, 7(1), 64-75.

Sudomo, A., \& Hani, A. (2014). Produktivitas talas (Colocasia esculenta L. Shott) di bawah tiga jenis tegakan dengan sistem agroforestri di lahan hutan rakyat. Jurnal Ilmu Kehutanan, 8(2), 100-107. 
Sumarno. (2016). Budaya konsumsi pangan, keanekaragaman pangan lokal dan pangan pokok alternatif. In E. Pasandaran, R. Heriawan, \& M. Syakir (Eds.), Pangan lokal: Budaya, potensi dan prospek pengembangan (pp. 53-76). Jakarta: IAARD Press.

Sumaryanto. (2004). Usahatani dan pendapatan rumah tangga petani padi: Studi kasus di persawahan DAS Brantas. In F. Kasryno, E. Pasandaran, \& A. M. Fagi (Eds.), Ekonomi padi dan beras Indonesia (pp. 225-252). Jakarta: Badan Penelitian dan Pengembangan Pertanian Departemen Pertanian.

Sumedi, \& Heriawan, R. (2016). Mengembalikan marwah pangan lokal pelajaran dari sejarah panjang pangan di Indonesia. In E. Pasandaran, R. Heriawan, \& M. Syakir (Eds.), Pangan lokal: Budaya, potensi dan prospek pengembangan (pp. 37-52). Jakarta: IAARD Press.

Suryana, A. (2016). Strategi pemanfaatan pangan lokal mendukung ketahanan pangan berkelanjutan. In E. Pasandaran, R. Heriawan, \& M. Syakir (Eds.), Pangan lokal: Budaya, potensi dan prospek pengembangan (pp. 480-504). Jakarta: IAARD Press.

Sutriadi, M. T., Sudarmaji, Iswadi, A., \& Prasojo, N. (2013). Atlas Zona Agro Ekologi DIY. Jakarta: Badan Penelitian dan Pengembangan Pertanian.

Titisari, A., \& Setyawan, B. (2018). Fulus dari umbi amorphophallus. Trubus, 582 Mei 2018/ XLIX, 20-23.

Tribun Jogja. (2017, 8 September 2017). Keberagaman pangan di DIY belum ideal. Tribun Jogja, pp. 13-14.

Vebriansyah, R., Setyawan, B., Ramadhan, M. F., \& Pratiwi, R. S. (2018). Mocaf makin moncer. Trubus, 582 Mei 2018/ XLIX, 12-15.

Versace, V. L., Ierodiaconou, D., Stagnitti, F., \& Hamilton, A. J. (2008). Appraisal of random and systematic land cover transitions for regional water balance and revegetation strategies. Agriculture, Ecosystems \& Environment, 123(4), 328-336. doi:https://doi.org/10.1016/j. agee.2007.07.012

Wang, J., Cheng, Q., \& Chen, J. (2011). A GIS and remote sensing-based analysis of land use change using the asymmetric relation analysis method: A case study from the City of Hangzhou, China. Mathematical Geosciences, 43(4), 435-453. doi:10.1007/s11004-011-9324-y

Watts, D., Leat, P., \& Revoredo-Giha, C. (2011). Local food activity in Scotland: Empirical evidence and research agenda. Regional Studies, 45(9), 1187-1205. doi:10.1080/00343400903380416

Whitten, T., Soeriaatmadja, R. E., \& Afiff, S. A. (2000). The ecology of Java and Bali. Singapore: Periplus Editions (HK) Ltd.

Widiyanto, D. (2018). An exploration of food insecurity, poverty, livelihood and local food potentials in Kulon Progo Regency, Indonesia. Forum Geografi, 32(1), 64-87.

Yusdja, Y. (1984). Latar belakang dan metodologi penelitian Patanas: Jawa Barat, Sumatera Barat, Sulawesi Selatan dan Jawa Timur. Forum penelitian Agro Ekonomi, 3(2), 1-4. 